\title{
Characterization of cover crops by NMR spectroscopy: impacts on soil carbon, nitrogen and phosphorus under tillage regimes ${ }^{1}$
}

\author{
Caracterização de plantas de cobertura por RMN: impactos nos teores de carbono, \\ nitrogênio e fósforo sob sistemas de manejo
}

\author{
Arminda Moreira de Carvalho ${ }^{2}$, Robélio Leandro Marchão $0^{2 *}$, Mercedes Maria da Cunha Bustamante ${ }^{3}$, Flávia \\ Aparecida de Alcântara ${ }^{4} \mathrm{e}$ Thais Rodrigues Coser $^{2}$
}

\begin{abstract}
The objective of this study was to investigate the chemical composition of cover crops by solid-state CPMAS ${ }^{13} \mathrm{C}$ NMR spectroscopy and its effects on carbon, nitrogen and phosphorus in a Typic Acrustox. Cover crops (Crotalaria juncea, Canavalia brasiliensis, Cajanus cajan, Mucuna pruriens and Raphanus sativus) and natural fallow were studied in rotation with maize under conventional and no-tillage regimes. Tissues of Crotalaria juncea, Canavalia brasiliensis, Mucuna pruriens and Raphanus sativus were analyzed using CPMAS ${ }^{13} \mathrm{C}$ NMR spectroscopy. Soil samples were collected at the end of the growing season of the cover crops (September 2002) and during the grain filling period in corn from 0-5 and 5-10 cm layers. Cajanus cajan presented the lowest content of polysaccharides and along with Mucuna pruriens presented the highest percentage of aromatic carbon compounds, reflecting the slow decomposition of highly lignified material. Carbon stocks were higher in the superficial soil layer and under no-tillage due to the accumulation and slower decomposition of plant tissues under these conditions. Increases in the $\mathrm{C} / \mathrm{N}$ ratio of the soil with Mucuna pruriens and the $\mathrm{C} / \mathrm{P}$ ratio with Cajanus cajan in the dry season were also related to slower rates of decomposition, caused by the large concentration of aromatic compounds in the tissues of these species. The higher $\mathrm{C} / \mathrm{P}$ ratios found at $0-5 \mathrm{~cm}$ layer are due to higher values of $\mathrm{P}$ (Mehlich-1) at 5-10 $\mathrm{cm} \mathrm{(25} \mathrm{mg} \mathrm{kg-1)} \mathrm{layer} \mathrm{and} \mathrm{the} \mathrm{higher} \mathrm{concentration}$ of carbon in the superficial soil layer as a result of the accumulation of plant residues.
\end{abstract}

Key words: Brazilian Savanna. Solid-state CPMAS ${ }^{13}$ C NMR spectroscopy. Organic matter. Ecological Intensification.

RESUMO - O objetivo deste trabalho foi avaliar os efeitos da composição química de plantas de cobertura por RMN de ${ }^{13} \mathrm{C}$ CPMAS no estado sólido sobre os estoques de $\mathrm{C}$ e $\mathrm{N}$, bem como, razões $\mathrm{C} / \mathrm{N}$ e $\mathrm{C} / \mathrm{P}$ em Latossolo Vermelho-Amarelo sob preparo convencional e sistema plantio direto. Amostras de tecidos das plantas de cobertura Crotalaria juncea, Canavalia brasiliensis, Mucuna pruriens, e Raphanus sativus foram analisadas por RMN de ${ }^{13} \mathrm{C}$ CPMAS no estado sólido. Amostras de solo para caracterização dos teores de C, N e P foram coletadas em duas épocas e nas camadas de 0-5 e 5-10 cm. A espécie Mucuna pruriens apresentou maiores concentrações de carbono do grupo de compostos aromáticos no tecido vegetal, refletindo uma menor decomposição desse material lignificado. Os estoques de carbono foram mais elevados na camada superficial no sistema plantio direto. Os incrementos da razão C/N no solo cultivado com Mucuna pruriens, na estação seca, resultaram da decomposição mais lenta dos resíduos vegetais que apresentaram maior concentração de compostos recalcitrantes (aromáticos) no tecido vegetal. A decomposição mais lenta do resíduo de Mucuna pruriens, principalmente, pela composição química com menor proporção de polissacarídeos em relação aos compostos aromáticos, também pode ter resultado nos valores de C/P mais elevados encontrados no solo cultivado com essa leguminosa. Os maiores valores de C/P na camada de 0-5 cm devem-se aos maiores teores de $\mathrm{P}$ (Mehlich-1) na camada de $5-10 \mathrm{~cm}\left(25 \mathrm{mg} \mathrm{kg}^{-1}\right)$ e também à maior concentração de $\mathrm{C}$ na superfície do solo pelo acúmulo dos resíduos vegetais.

Palavras-chave: Cerrado. Ressonância magnética nuclear de ${ }^{13} \mathrm{C}$ no estado sólido. matéria orgânica. intensificação ecológica.

\footnotetext{
*Autor para correspondência

${ }^{1}$ Recebido para publicação em 06/03/2014; aprovado em 23/09/2014

Trabalho financiado pela EMBRAPA e CNPq

${ }^{2}$ Embrapa Cerrados, BR 020, Km 18, Caixa Postal 08223, Planaltina-DF, Brasil, 73.310-970, arminda.carvalho@embrapa.br, robelio.marchao@ embrapa.br, thacoser@gmail.com

${ }^{3}$ Departamento de Ecologia, Universidade de Brasília, Asa Norte, Brasília-DF, Brasil, 70.919-970, mercedes@unb.br

${ }^{4}$ Embrapa Arroz e Feijão, Rodovia GO-462, Km 12, Caixa Postal 179, Santo Antônio de Goiás-GO, flavia.alcantara@embrapa.br
} 


\section{INTRODUCTION}

The quantity and chemical composition of plant tissues affect the decomposition process and subsequently the formation of organic matter in terrestrial ecosystems (CLEMENTE et al., 2013; DING et al., 2006). The susceptibility of plant tissues to decomposition is associated with their chemical composition, principally lignin and polyphenol levels. Plant tissues with low levels of nitrogen and phosphorus and high levels of lignin and polyphenols present low rates of decomposition and slow release of nutrients (CARVALHO et al., 2012; TALBOT et al., 2012).

The decomposition of plants involves initial loss of carbohydrates (cellulose and hemicellulose) and then the slow transformation of aromatic structures in the lignin molecules, followed by highly recalcitrant carbon (alkyls) (KÖGEL-KNABNER, 2000). Through studies employing solid-state nuclear magnetic resonance (NMR) the main differences in the chemical composition of plant tissues are associated with differences in signal intensities of the alkyl$\mathrm{C}$ and $\mathrm{O}$-alkyl regions; alkyl-C is mainly associated with aliphatic carbons such as lipid waxes, cutins and microbial products and O-alkyl characteristics of O-substituted alkyl carbon in carbohydrates, but also includes methoxyl carbon and N-substituted alkyl carbon in protein (ALCÂNTARA $e t$ al., 2004; CLEMENTE et al., 2013). The relative amount of alkyl-C increases during the decomposition process, mainly in the initial phase, while the amount of O-alkyl decreases (BAUMANN et al., 2009). Therefore, considering the influence of carbon compounds on the decomposition process, Baldock et al. (1992) suggested that the ratio between alkyls-C and O-alkyls could be used as an index of decomposition dynamics. In addition, other attributes of organic groups can be used, such as the aromaticity and the hydrophobicity ratio (HATCHER et al., 1981). These ratios have been applied also in studies employing NMR of ${ }^{13} \mathrm{C}$ with cross-polarization $(\mathrm{CP})$ and magic angle spinning (MAS) (CPMAS- $\left.{ }^{13} \mathrm{C}-\mathrm{NMR}\right)$ to complement information on chemical composition of plant tissues and its effect on soil organic matter (ALCÂNTARA et al., 2004).

These characteristics that influence plant residue decomposition can also alter the dynamics of carbon, nitrogen and phosphorus in the soil (CHIVENGE et al., 2011). Soil management systems such as the use of notillage techniques and rotation with cover crops have also an effect on the accumulation of $\mathrm{C}, \mathrm{N}$ and $\mathrm{P}$ in the soil (DIECKOW et al., 2005a; GRANDY et al., 2008; METAY et al., 2007; SÁ et al., 2014; TIVET et al., 2013). Considering 31,5 million hectares under no-tillage in Brazil in 2012 (FEBRAPDP, 2012) and that an increase of 8 million hectares by 2020 has been planned by the Brazilian government as one of the main approaches for greenhouse gas mitigation (BRASIL, 2012), more information is needed on the chemical composition of decomposing plant residues and their influence on the stocks of carbon and other nutrients. Moreover, one of the basic requirements for the implementation and maintenance of no-tillage in Brazil is the adequate production of plant residues in order to keep the soil surface continuously covered and to recycle nutrients and gradually make them available to successive crops (CRUSCIOL et al., 2013).

The objective of this study was to evaluate the impact of the chemical composition of decomposing plant tissues on the stocks of $\mathrm{C}$ and $\mathrm{N}$ and $\mathrm{C} / \mathrm{N}$ and $\mathrm{C} / \mathrm{P}$ ratios in an Typic Acrustox under conventional and no-tillage.

\section{MATERIAL AND METHODS}

\section{Characterization of the experimental area}

A cultivation system involving succession of maize and cover crops was maintained continuously over six years at Planaltina, Federal District, on a Typic Acrustox in a Tropical Savanna climate (Aw). Texture and chemical characterization of the soil are presented in Table 1. Data on rainfall and average temperatures for the 2002/2003 crop season (Figure 1) were collected at the EMBRAPA Cerrados weather station.

Mineral fertilization was carried out at the start of the experiment in January 1997 using $180 \mathrm{~kg} \mathrm{ha}^{-1} \mathrm{P}_{2} \mathrm{O}_{5}$ in the form of simple superphosphate, $60 \mathrm{~kg} \mathrm{ha}^{-1} \mathrm{~K}_{2} \mathrm{O}$ in as potassium chloride and $50 \mathrm{~kg} \mathrm{ha}^{-1}$ of FTE BR-10 as a source of micronutrients. In addition, $500 \mathrm{~kg} \mathrm{ha}^{-1}$ of gypsum $\left(\mathrm{CaSO}_{4}\right)$ was applied to the area. Maize was cultivated under no-tillage and conventional system (with incorporation of plant residues employing disc plough and harrow). Fertilizers were incorporated with the plant residues before maize sowing using a disk harrow in subplots under tillage or applied on the soil surface under no-tillage. The cover crops were sown at the end of the rainy season following a maize crop in both conventional tillage and no-tillage sub-plots. Cover crops included: Crotalaria juncea L., Canavalia brasiliensis Mart. ex Benth, Cajanus cajan L. Millsp. cv. Kaki, Mucuna pruriens (L.) DC and Raphanus sativus L. The reference treatment involved the absence of cover crops (spontaneous vegetation during off season).

The experimental design was randomized complete block with experimental units repeated three times. Cover crops were sown into experimental units $(12 \times 30 \mathrm{~m})$ and the management of the plant residues (incorporated or not incorporated into the soil) represented the subunits $(12 \times 15 \mathrm{~m})$. Cover crops were sown directly onto the crop residues of the maize. 
Table 1 - Soil physical and chemical characteristics (mean for $\mathrm{n}=20$ samples) for the $0-20 \mathrm{~cm}$ depth of a Typic Acrustox in Planaltina, Federal District, Brazil

\begin{tabular}{lc}
\hline \multicolumn{1}{c}{ Soil properties } & $96 / 97$ \\
\hline Clay $\left(\mathrm{g} \mathrm{kg}^{-1}\right)$ & 513 \\
Silt $\left(\mathrm{g} \mathrm{kg}^{-1}\right)$ & 186 \\
Sand $\left(\mathrm{g} \mathrm{kg}^{-1}\right)$ & 301 \\
$\mathrm{pH}\left(\mathrm{H}_{2} \mathrm{O}\right)$ & 6.2 \\
Organic matter $\left(\mathrm{g} \mathrm{kg}^{-1}\right)$ & 23.6 \\
Exchangeable aluminium $\left(\mathrm{cmol}_{\mathrm{c}} \mathrm{kg}^{-1}\right)$ & 0.01 \\
Potential acidity $(\mathrm{H}+\mathrm{Al}):\left(\mathrm{cmol}_{\mathrm{c}} \mathrm{kg}^{-1}\right)$ & 3.34 \\
Exchangeable cations $/ \mathrm{S}-\mathrm{Value}: \mathrm{Ca}^{2+}+\mathrm{Mg}^{2+}+\mathrm{K}^{+}\left(\mathrm{cmol}_{\mathrm{c}} \mathrm{kg}^{-1}\right)$ & 3.4 \\
Cation exchange capacity: S-Value $+\left(\mathrm{H}^{-\mathrm{Al}}\right)\left(\mathrm{cmolc} \mathrm{kg}^{-1}\right)$ & 6.8 \\
Base saturation/V-value $(\%)$ & 50 \\
$\mathrm{P}_{\text {Mehlich-1 }}(\mathrm{mg} \mathrm{kg})$ & 3.4 \\
\hline
\end{tabular}

Figure 1 - Distribution of rains and average temperatures during the 2002/2003 crop season, Planaltina, Federal District (EMBRAPA Cerrados weather station)

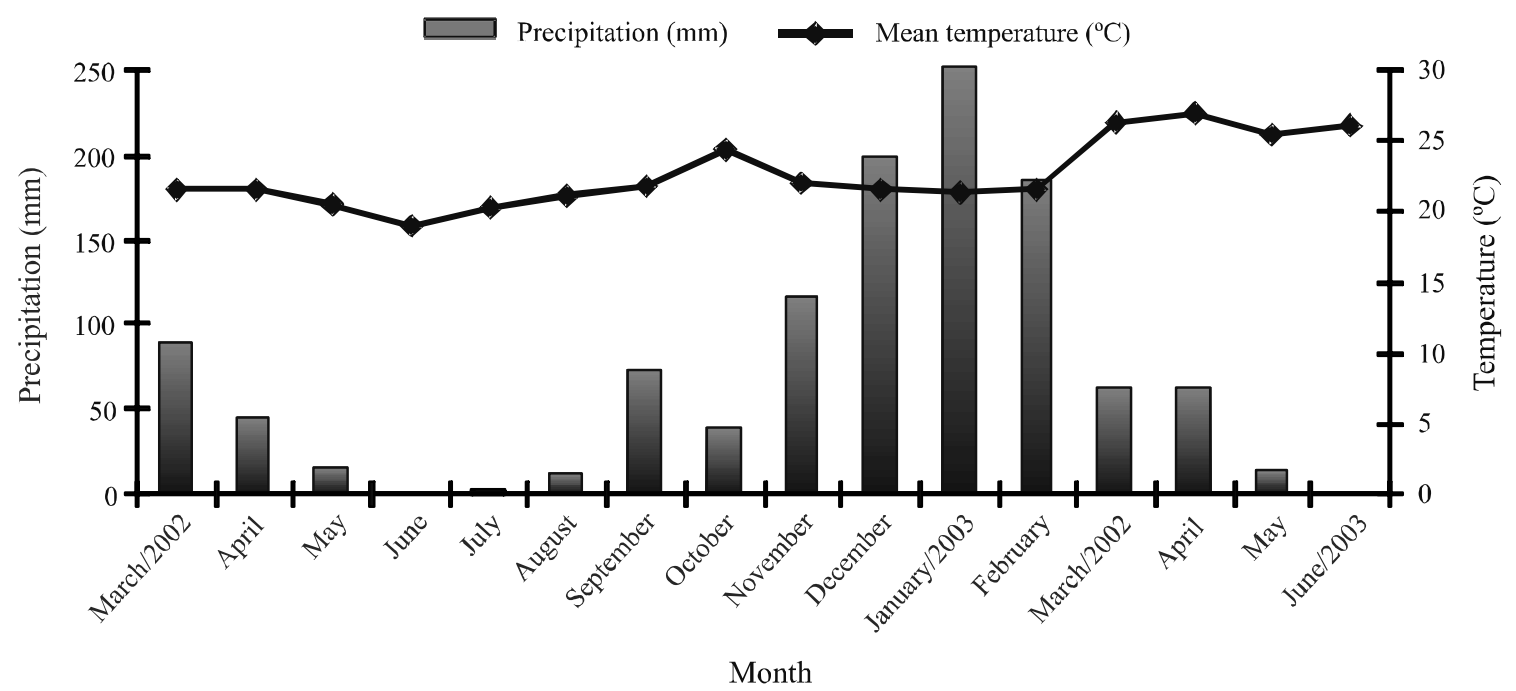

In 2002, before the maize was planted, $1,440 \mathrm{~g}$ ai ha-1 of glyphosate (glyphosate isopropylamine salt) was applied to the subplots under no-tillage to desiccate weeds and reduce cover crops regrowth. The maize was sown in $7^{\text {th }}$ November 2002, with $0.90 \mathrm{~m}$ row spacing and a stand of 55,000 plants ha ${ }^{-1}$. The plots were fertilized with $20 \mathrm{~kg} \mathrm{ha}^{-1} \mathrm{~N}, 150 \mathrm{~kg} \mathrm{ha}^{-1} \mathrm{P}_{2} \mathrm{O}_{5}$ and $80 \mathrm{~kg} \mathrm{ha}^{-1} \mathrm{~K}_{2} \mathrm{O}$, as well as $50 \mathrm{~kg} \mathrm{ha}^{-1} \mathrm{~N}$ applied as top dressing with the opening of the sixth leaf pair. The $\mathrm{N}$ treatment was repeated when the plant presented the eighth leaf pair and with the appearance of female inflorescence, giving a total of $150 \mathrm{~kg} \mathrm{ha}^{-1}$ of $\mathrm{N}$ applied as top dressing.

\section{Characterization of the chemical composition of the plant tissues}

The sampling of aboveground biomass and the analysis of chemical composition for the cover crops were carried out with the plants being cut close to soil surface (two repetitions of $1 \mathrm{~m}^{2}$ per subplot) during the period between the beginnings of flowering and when $50 \%$ of plants had flowered. To obtain the weight of the dry matter, the material was maintained in an air circulating oven at $65^{\circ} \mathrm{C}$ until it reached constant weight and a small part was ground and analyzed for chemical composition. 
Plant tissues samples of Crotalaria juncea, Canavalia brasiliensis, Cajanus cajan, Mucuna pruriens e Raphanus sativus were analyzed using CPMAS ${ }^{13} \mathrm{C}$-NMR. Integration of the spectra (ppm) corresponded to the following organic groups: alkyls (0-45 ppm), O-alkyls (45-110 ppm), aromatic carbon compounds (110-160 ppm) and carbonyls/acyls (160$230 \mathrm{ppm})$.

\section{Soil samples and analysis}

In September 2002 (dry season), soil samples from the 0 to $5 \mathrm{~cm}$ soil layers were collected from eight $45 \times 3 \times 5 \mathrm{~cm}$ trenches per subplot. Soil samples from the 5 to $10 \mathrm{~cm}$ soil layers were taken from the bottom of the trenches (three cores per trench) with the use of a Dutch auger and combined to form a plot composite sample. Additional soil samples were also taken during the grain filling period in corn (rainy season), in February 2003 perpendicularly from the maize sowing line, which was centralized in a $90 \times 3$ $\mathrm{x} 5 \mathrm{~cm}$ trench. Finally, all samples were air-dried, then manually crushed to pass through a $2 \mathrm{~mm}$ sieve.

To determine bulk density, four undisturbed samples were collected from depths of $0-5 \mathrm{~cm}$ and 5$10 \mathrm{~cm}$ from each subplot using $100 \mathrm{~cm}^{3}$ cylinders. Total organic carbon was obtained using the wet oxidation method (WALKLEY; BLACK, 1934). Total nitrogen was determined via sulphuric digestion using the Kjeldahl steam distillation technique, while available phosphorus was determined using the Mehlich-1 method (hydrochloric acid - $\mathrm{HCl} 0.05 \mathrm{~N}$ and sulphuric acid - $\mathrm{H}_{2} \mathrm{SO}_{4} 0.025 \mathrm{~N}$ ) (EMBRAPA, 1997). The $\mathrm{C} / \mathrm{N}$ and $\mathrm{C} / \mathrm{P}$ ratios were then calculated. Calculations of $\mathrm{C}$ and $\mathrm{N}$ stocks were carried out by multiplying the carbon and nitrogen contents by the soil density in each soil layer $(0-5 \mathrm{~cm}$ and $5-10 \mathrm{~cm})$.

\section{Statistical analysis}

An analysis of variance was applied considering repeated data over the time and space. The cover crops representing the main factor (plot), the tillage system representing secondary factor (subplot), the space (subsubplot) is represented by different depth (0-5 and $5-10 \mathrm{~cm}$ layer), the time (subsubsubplot) is represented by the different season (rain season and dry season). Thus the analysis of variance with repeated-measures (ANOVA) was applied to evaluate the effects of the four factors and all interactions between these factors, based on the split-plot design with repeatedmeasurements. These analyses were performed using the SAS PROC MIXED procedure (SAS Institute, 2000). Mean comparisons were made using the Tukey test at $5 \%$ significance level.

\section{RESULTS AND DISCUSSION}

Relatively lower rates of aromatic compounds or more stable alkyls found in Crotalaria juncea, Canavalia brasiliensis and Raphanus sativa (Table 2) may have contributed to the faster rate of decomposition of their plant tissues (CARVALHO et al., 2008; 2012; TALBOT et al., 2012). These species presented decomposition rates of around $90 \%$ at the end of an evaluation period of 90 days, mainly under management involving incorporation of its tissues in the Cerrado region (CARVALHO et al., 2008). Cajanus cajan stood out as its less stable compounds (polysaccharides) are present to a lower degree than the lignified material containing aromatic groups and recalcitrant carbon compounds from the alkyl region (Table 2). Mucuna pruriens has also shown high levels of aromatic compounds and together with Cajanus cajan have slower rate of decomposition in no-tillage and conventional systems (CARVALHO et al., 2008).

Results from Crusciol et al. (2013) and Balota; Chaves (2011) show that the $\mathrm{C} / \mathrm{N}$ ratio of Mucuna pruriens (16.4) is lower than that from Cajanus cajan (32). However, the chemical composition of these leguminous crops is similar, particularly in the aromatic carbon compound region, confirming the relationship between the composition of carbon compounds and the decomposition of plant material (RANDAL et al., 1997). Studies such as those from Carvalho et al. (2012) demonstrate that the $\mathrm{C} / \mathrm{N}$ ratio alone does not give an accurate representation of the decomposition process of organic material, while chemical composition semi-quantified by CPMAS ${ }^{13} \mathrm{C}$-NMR determines the relative contribution of the main carbon groups present in the plant material, or in other words the quality of the carbon.

Carbon stocks in the soil were different between management systems (conventional and no-tillage) (Table 3). No-tillage has shown to increase carbon stocks during the rainy season in the surface layer $(0-5 \mathrm{~cm})$ possibly due to the aboveground plant biomass returned to the soil surface and its slower decomposition of plant residues in the soil under this condition (MARTINS et al., 2012). Metay et al. (2007) under Oxisol observed a tendency of soil $\mathrm{C}$ stocks to increase under no-tillage compared to conventional system in the $0-10 \mathrm{~cm}$ soil layer. Although, variations in the content of organic groups were observed within cover crops, suggesting that the composition of plant residues present a weak effect on soil carbon stocks. Dieckow et al. (2005a) studying the effect of cropping systems observed that the composition of organic matter in the soil (in terms of O-alkyl, alkyls, aromatic and carbonyl C) was not 
Table 2 - Relative percentage of organic groups in cover crops through CPMAS ${ }^{13} \mathrm{C}-\mathrm{NMR}$ determination

\begin{tabular}{|c|c|c|c|c|}
\hline \multirow{2}{*}{ Cover crop } & \multicolumn{4}{|c|}{ Percentage in relation to organic groups } \\
\hline & Carbonyl/acyl & Aromatic & O-alkyl & Alkyl \\
\hline Crotalaria juncea & $7.5(\mathrm{a})$ & $9.9(\mathrm{ab})$ & $69.2(\mathrm{a})$ & 13.4 (c) \\
\hline Canavalia brasiliensis & 11.0 (a) & $7.5(\mathrm{bc})$ & $65.5(\mathrm{a})$ & $16.0(\mathrm{bc})$ \\
\hline Cajanus cajan & 11.4 (a) & 11.7 (a) & $56.4(\mathrm{~b})$ & 20.5 (a) \\
\hline Mucuna pruriens & 6.7 (a) & $12.1(\mathrm{a})$ & $67.5(\mathrm{a})$ & $13.7(\mathrm{c})$ \\
\hline Raphanus sativus & $10.5(\mathrm{a})$ & 5.7 (c) & 65.9 (a) & $17.9(\mathrm{ab}$ \\
\hline $\mathrm{CV} \%$ & 36.5 & 21.1 & 7.8 & 18.2 \\
\hline
\end{tabular}

Averages followed by different lower-case letters along each column differed according to the Tukey test at $5 \%$ probability level

Table 3 - Carbon stocks in the soil with cover crops under conventional and no-tillage regimes during the dry and rainy seasons, considering depths of 0-5 and 5-10 cm during the 2002/2003 crop season, Planaltina, Federal District

\begin{tabular}{|c|c|c|c|c|}
\hline \multirow{3}{*}{ Cover crop } & \multicolumn{4}{|c|}{ Carbon stocks $\left(\mathrm{Mg} \mathrm{ha}^{-1}\right)$} \\
\hline & \multicolumn{2}{|c|}{$0-5 \mathrm{~cm}$} & \multicolumn{2}{|c|}{$5-10 \mathrm{~cm}$} \\
\hline & Dry & Rainy & Dry & Rainy \\
\hline Crotalaria juncea & $7.2(\mathrm{a}) \mathrm{B}$ & 8.7 (a)A & $7.0(\mathrm{a}) \mathrm{A}$ & $7.5(\mathrm{a}) \mathrm{A}$ \\
\hline Canavalia brasiliensis & 7.5 (a)A & 7.9 (a)A & 7.3 (a)A & 7.8 (a)A \\
\hline Cajanus cajan & $7.4(\mathrm{a}) \mathrm{A}$ & $8.4(\mathrm{a}) \mathrm{A}$ & $6.8(\mathrm{a}) \mathrm{A}$ & 7.8 (a)A \\
\hline Mucuna pruriens & 8.1 (a)A & 8.5 (a)A & $7.0(\mathrm{a}) \mathrm{B}$ & 7.7 (a)A \\
\hline Raphanus sativus & 8.0 (a)A & 7.9 (a)A & $6.8(\mathrm{a}) \mathrm{B}$ & $8.2(\mathrm{a}) \mathrm{A}$ \\
\hline Spontaneous vegetation & $7.4(\mathrm{a}) \mathrm{A}$ & 8.4 (a)A & 6.7 (a)A & 7.3 (a)A \\
\hline \multicolumn{5}{|l|}{ Management system } \\
\hline Conventional tillage & 7.4 (a) & 7.8 (b) & $7.2(\mathrm{a})$ & 7.9 (a) \\
\hline No-tillage & 7.7 (a) & 8.9 (a) & $6.6(b)$ & 7.5 (a) \\
\hline $\mathrm{CV} \%$ & \multicolumn{4}{|c|}{7.8} \\
\hline
\end{tabular}

Averages followed by different lower-case letters along each column and upper-case letters in each row differed according to the Tukey test at $5 \%$ probability level

affected by different crops grown. However, both land use and the use of cover crops (Panicum maximum, pigeon pea, oat, sunflower) affected the composition and quantity of the particulate fraction of organic matter (COSER et al., 2012; DIECKOW et al., 2005a; MARTINS et al., 2012). The particulate fraction of the organic matter represents only between 5 and $22 \%$ of the total carbon in the soil (DIECKOW et al., 2005b) and together with plant litter serve as primary sources of soil microbial carbon (GRANDY et al., 2008).

Nitrogen stocks in the soil did not differ between cover crops and the management systems (Table 4). Increases in the $\mathrm{C} / \mathrm{N}$ ratio were observed under Mucuna pruriens during the dry season and at $0-5 \mathrm{~cm}$ layer of soil (Table 5) owing to the higher concentration of recalcitrant aromatic compounds in the plant tissue of this specie. Although Cajanus cajan has high concentration of more stable compounds (aromatic compounds and alkyls) it did not promote a higher $\mathrm{C} / \mathrm{N}$ ratio in the soil, possibly due to its lower production of biomass (CARVALHO et al., 2008; CRUSCIOL et al., 2013) and maize straw in the plots with this cover crop.

The C/P ratio (Table 6) in the plot with Cajanus cajan during the dry season resulted in the slower decomposition of plant residues owing to the higher concentration of recalcitrant aromatic compounds in the plant tissue of this specie. The values of the $\mathrm{C} / \mathrm{N}$ and $\mathrm{C} /$ $\mathrm{P}$ ratios in plants expresses its durability as cover crops in the no-tillage (CRUSCIOL et al., 2013; SORATTO et al., 2012). The slower decomposition of Cajanus cajan and Mucuna pruriens residues, mainly due to lower levels of polysaccharides compared to more stable aromatic 
Table 4 - Nitrogen stocks in the soil under conventional and no-tillage regimes at depths of 0-5 and 5-10 cm, considering the dry and rainy seasons during the 2002/2003 crop season, Planaltina, Federal District

\begin{tabular}{lcccc}
\hline \multirow{2}{*}{ Management system } & \multicolumn{5}{c}{ Nitrogen stocks $\left(\mathrm{Mg} \mathrm{ha}^{-1}\right)$} \\
\cline { 2 - 5 } & $0-5 \mathrm{~cm}$ & $5-10 \mathrm{~cm}$ & Dry & Rainy \\
\hline Conventional & 0.8 & 0.8 & 0.8 & 0.8 \\
No-tillage & 0.9 & 0.7 & 0.8 & 0.9 \\
\hline CV \% & \multicolumn{5}{c}{19.4} \\
\hline
\end{tabular}

Table $5-\mathrm{C} / \mathrm{N}$ ratio of the soil with cover crops at depths of $0-5$ and $5-10 \mathrm{~cm}$, considering the dry and rainy seasons during the 2002/2003 crop season, Planaltina, Federal District

\begin{tabular}{lrrrr}
\hline \multirow{2}{*}{ Cover crop } & \multicolumn{4}{c}{ C/N ratio } \\
\cline { 2 - 5 } & \multicolumn{3}{c}{ Dry } & \multicolumn{3}{c}{ Rainy } \\
\cline { 2 - 5 } & $0-5 \mathrm{~cm}$ & $10.0(\mathrm{a}) \mathrm{A}$ & $10.4(\mathrm{a}) \mathrm{A}$ & $5-10 \mathrm{~cm}$ \\
\hline Crotalaria juncea & $9.5(\mathrm{~b}) \mathrm{A}$ & $10.5(\mathrm{a}) \mathrm{A}$ & $10.1(\mathrm{a}) \mathrm{A}$ & $9.8(\mathrm{a}) \mathrm{A}$ \\
Canavalia brasiliensis & $9.1(\mathrm{~b}) \mathrm{A}$ & $9.5(\mathrm{a}) \mathrm{A}$ & $10.9(\mathrm{a}) \mathrm{A}$ & $9.8(\mathrm{a}) \mathrm{A}$ \\
Cajanus cajan & $9.9(\mathrm{~b}) \mathrm{A}$ & $9.9(\mathrm{a}) \mathrm{B}$ & $11.0(\mathrm{a}) \mathrm{A}$ & $9.4(\mathrm{a}) \mathrm{A}$ \\
Mucuna pruriens & $18.0(\mathrm{a}) \mathrm{A}$ & $9.5(\mathrm{a}) \mathrm{A}$ & $9.8(\mathrm{a}) \mathrm{A}$ & $10.4(\mathrm{a}) \mathrm{A}$ \\
Raphanus sativus & $10.3(\mathrm{~b}) \mathrm{A}$ & $10.0(\mathrm{a}) \mathrm{A}$ & $10.2(\mathrm{a}) \mathrm{A}$ & $8.6(\mathrm{a}) \mathrm{A}$ \\
Spontaneous vegetation & $9.4(\mathrm{~b}) \mathrm{A}$ & \multicolumn{3}{c}{26.1} \\
\hline CV $(\%)$ & & & \\
\hline
\end{tabular}

Averages followed by different lower-case letters along each column and upper-case letters in each row per season differed according to the Tukey test at $5 \%$ probability level

Table 6 - $\mathrm{C} / \mathrm{P}_{\text {Mehlich-1 }}$ ratio of the soil with cover crops under conventional and no-tillage regimes at depths of 0-5 and 5-10 cm, considering the dry and rainy seasons during the 2002/2003 crop season, Planaltina, Federal District

\begin{tabular}{|c|c|c|c|c|}
\hline \multirow{3}{*}{ Cover crop } & \multicolumn{4}{|c|}{$\mathrm{C} / \mathrm{P}_{\text {Mehlich-1 }}$ ratio } \\
\hline & \multicolumn{2}{|c|}{ Dry } & \multicolumn{2}{|c|}{ Rainy } \\
\hline & $0-5 \mathrm{~cm}$ & $5-10 \mathrm{~cm}$ & $0-5 \mathrm{~cm}$ & $5-10 \mathrm{~cm}$ \\
\hline Crotalaria juncea & 1197 (bc)A & $1953(\mathrm{ab}) \mathrm{A}$ & 2882 (a)A & 505 (a)B \\
\hline Canavalia brasiliensis & $1723(\mathrm{abc}) \mathrm{A}$ & 1291 (b)A & $1714(\mathrm{c}) \mathrm{A}$ & 761 (a)B \\
\hline Cajanus cajan & 2146 (a)A & $1879(\mathrm{ab}) \mathrm{A}$ & $2341(a b) A$ & 574 (a)B \\
\hline Mucuna pruriens & $2022(a b) A$ & 1478 (b)A & $2666(a b) A$ & 650 (a)B \\
\hline Raphanus sativus & $1540(\mathrm{abc}) \mathrm{A}$ & 1429 (b)A & $2051(\mathrm{bc}) \mathrm{A}$ & 947 (a)B \\
\hline Spontaneous vegetation & $1103(\mathrm{c}) \mathrm{A}$ & $1190(\mathrm{bc}) \mathrm{A}$ & $1997(\mathrm{bc}) \mathrm{A}$ & 474 (a)B \\
\hline \multirow{2}{*}{ Management system } & \multicolumn{2}{|c|}{ Dry } & \multicolumn{2}{|c|}{ Rainy } \\
\hline & $0-5 \mathrm{~cm}$ & $5-10 \mathrm{~cm}$ & $0-5 \mathrm{~cm}$ & $5-10 \mathrm{~cm}$ \\
\hline Conventional tillage & 1662 (a)A & 1891 (a)A & 2173 (a)A & 741 (a)B \\
\hline No-tillage & 1593 (a)A & 1424 (a)A & 2437 (a)A & 505 (a)B \\
\hline $\mathrm{CV}(\%)$ & \multicolumn{4}{|c|}{51.2} \\
\hline
\end{tabular}

Averages followed by different lower-case letters along each column and upper-case letters in each row per season differed according to the Tukey test at $5 \%$ probability level 
compounds (lignified material) (CARVALHO et al., 2012; TALBOT et al., 2012), could have caused the higher C/P ratios found for this species at depths of $0-5 \mathrm{~cm}$ during the dry season. Higher $\mathrm{C} / \mathrm{P}$ ratios in the $0-5 \mathrm{~cm}$ soil layer compared to the $5-10 \mathrm{~cm}$ layer were caused by lower levels of available $\mathrm{P}$ at $0-5 \mathrm{~cm}$ compared to at $5-10 \mathrm{~cm}$ layer, and by much higher concentration of carbon at the soil surface caused by the accumulation of plant residues, principally maize straw (CARVALHO et al., 2014).

Lower yields of maize (CARVALHO et al., 2008) were obtained for the crop season studied in areas with Cajanus cajan and Mucuna pruriens, which could be related to the slower decomposition of these cover crops residues. Crusciol et al. (2013) comparing Cajanus cajan and pearl millet observed that the last is more indicated for no-tillage in regions with dry winters specially because of its higher macronutrient cycling. However, Cajanus cajan and Mucuna pruriens are recommended for crop coverage under no-tillage.

Positive results related to fertility parameters has been obtained with the incorporation of plant residues in the soil, which are attributed to faster rates of decomposition and thus faster release of nutrients (ALCÂNTARA et al., 2000) as a result of the original limited levels of nitrogen and phosphorus in the soil found in the Brazilian Savanna.

\section{CONCLUSIONS}

1. Cajanus cajan and Mucuna pruriens plant tissues present higher concentration of aromatic compounds and consequently a slower rate of decomposition compared to Crotalaria juncea, Raphanus sativa and Canavalia brasiliensis, which have lower relative rates of aromatic carbon compounds and alkyls;

2. Carbon and nitrogen stocks vary between soil management (conventional and no-tillage regimes);

3. Soil under Mucuna pruriens present higher $\mathrm{C} / \mathrm{N}$ ratio compared to other cover crops in the $0-5 \mathrm{~cm}$ soil layer during the dry season;

4. Soil under Cajanus cajan tend to have higher $\mathrm{C} / \mathrm{P}$ ratio in the $0-5 \mathrm{~cm}$ soil layer during.

\section{ACKNOWLEDGEMENTS}

We would like to thank Sebastião de Souza Lemos and Inês Sabioni Resck from Chemical Department, University of Brasília, for his help in NMR analysis.

\section{REFERENCES}

ALCÂNTARA, F. A. de et al. Changes in soil organic matter composition after introduction of riparian vegetation on shores of hydroelectric reservoirs (Southeast of Brazil). Soil Biology \& Biochemistry, v. 36, p. 1497-1508, 2004.

ALCÂNTARA, F. A. de et al. Adubação verde na recuperação da fertilidade de um Latossolo Vermelho-Escuro degradado. Pesquisa Agropecuária Brasileira, v. 35, p. 277-288, 2000.

BALDOCK, J. A. et al. Aspects of the chemical structure of soil organic materials as revealed by solid-state ${ }^{13} \mathrm{C}$ NMR spectroscopy. Biogeochemistry, v. 16, p. 1-42, 1992.

BALOTA, E. L.; CHAVES, J. C. D. Microbial activity in soil cultivated with different summer legumes in coffee crop. Brazilian Archives of Biology and Technology, v.54, p.3544, 2011.

BAUMANN, K. et al. Residue chemistry and microbial community structure during decomposition of eucalypt, wheat and vetch residues. Soil Biology \& Biochemistry, v. 41, p. 19661975, 2009.

BRASIL. Plano setorial de mitigação e de adaptação às mudanças climáticas para a consolidação de uma economia de baixa emissão de carbono na agricultura : plano ABC (Agricultura de Baixa Emissão de Carbono) / Ministério da Agricultura, Pecuária e Abastecimento, Ministério do Desenvolvimento Agrário, coordenacão da Casa Civil da Presidencia da República. - Brasília: MAPA/ACS, 2012. 173 p.

CARVALHO, A. M. de et al. Decomposição de resíduos vegetais em Latossolo sob cultivo de milho e plantas de cobertura. Revista Brasileira de Ciência do Solo, v. 32, p. 2831-2838, 2008.

CARVALHO, A. M. et al. Chemical composition of cover plants and its effect on maize yield in no-tillage systems in the Brazilian savanna. Crop \& Pasture Science, v. 63, p. 10751081, 2012

CARVALHO, A. M. et al. Forms of phosphorus in an oxisol under different soil tillage systmes and cover plants in rotation with maize. Revista Brasileira de Ciência do Solo, v. 38, p. 972-979, 2014.

CHIVENGE, P. et al. Organic resource quality influences short-term aggregate dynamics and soil organic carbon and nitrogen accumulation. Soil Biology \& Biochemistry, v. 43, n.3, p. 657-666, 2011.

CLEMENTE, J. S. et al. Comparison of soil organic matter composition after incubation with maize leaves, roots, and stems. Geoderma v. 192, p. 86-96, 2013.

COSER, T. R. et al. Recuperação de carbono obtida por três métodos em fraçõeses da matéria orgânica de Latossolo sob consórcio milho forrageiras, no Cerrado. Bioscience Journal, v. 28, p.91-97, 2012.

CRUSCIOL, C. A. C. et al. Cycling of nutrients and silicon in pigeonpea and pearl millet monoculture andn intercropping. Revista Brasileira de Ciência do Solo, v. 37, p. 1628-1640, 2013. 
DIECKOW, J. et al. Composition of organic matter in a subtropical Acrisol as influenced by land use, cropping and $\mathrm{N}$ fertilization, assessed by CPMAS 13C NMR spectroscopy. European Journal of Soil Science, v. 56, p. 705-715, 2005a.

DIECKOW, J. et al. Carbon and nitrogen stocks in soil physical fractions as influenced by cropping systems and $\mathrm{N}$ fertilization under long-term no-tillage management. Plant and Soil, v. 268, n. 1, p. 319-328, 2005b.

DING, G. et al. Effect of cover crop management on soil organic matter. Geoderma, v.130, p. 229-239, 2006.

EMPRESA BRASILEIRA DE PESQUISA AGROPECUÁRIA. Centro Nacional de Pesquisa de Solos (Rio de Janeiro, RJ). Manual de métodos de análise de solo. Centro Nacional de Pesquisa de Solos. 2. ed. ver. Atual- Rio de Janeiro, 1997. 212 p.

FEBRAPDP - FEDERAC,ÃO BRASILEIRA DE PLANTIO DIRETO NA PALHA. Evoluc,ão do plantio direto no Brasil. Disponível em <http://www.febrapdp.org.br/port/ plantiodireto.html>. Acesso em: 03 fevereiro 2014.

GRANDY, A. S.; NEFF, J. C. Molecular C dynamics downstream: The biochemical decomposition sequence and its impact on soil organic matter structure and function. Science of the Total Environment, v. 404, n. 2-3, p. 297307, 2008.

HATCHER, P. G. et al. Aromaticity of humic substances in soils. Soil Science Society of America Journal, v. 45, p. 10891094, 1981.

KÖGEL-KNABER, I. Analytical approaches for characterizing soil organic matter. Organic Geochemistry, v. 31, p. 609-625, 2000 .

MARTINS, M. R.; ANGERSB, D. A.; CORÁ, J. E. Coaccumulation of microbial residues and particulate organic matter in the surface layer of a no-till Oxisol under different crops. Soil Biology \& Biochemistry, v. 50, p. 208-213, 2012.

METAY, A. et al. Storage and forms of organic carbon in a no-tillage under cover crops system on clayey Oxisol in dryland rice production (Cerrados, Brazil). Soil \& Tillage Research, v. 94, p. 122-132, 2007.

RANDAL, E. W.; MAHIEU, N.; IVANOVA, G. I. NMR studies of soil, soil organic matter and nutrients: spectroscopy and imaging. Geoderma, v. 80, p. 307-325, 1997.

SÁ, J. C. et al. Long-term tillage systems impacts on soil $\mathrm{C}$ dynamics, soil resilience and agronomic productivity of a Brazilian Oxisol. Soil \& Tillage Research, v. 136, p. 38-50, 2014.

SAS INSTITUTE INC., System for Microsoft Windows. Release 8.01. Cary: NC, USA, CD-Rom, 2001.

SORATTO, R. P. et al. Produção, decomposição e ciclagem de nutrientes em resíduos de crotalária e milheto, cultivados solteiros e consorciados. Pesquisa Agropecuária Brasileira, v. 47, p. 1462-1470, 2012.

TALBOT, J. M. et al. Litter decay rates are determined by lignin chemistry. Biogeochemistry, v. 108, p. 279-295. 2012.

TIVET, F. et al. Aggregate C depletion by plowing and its restoration by diverse biomass- $\mathrm{C}$ inputs under no-till in sub-tropical and tropical regions of Brazil. Soil \& Tillage Research, v. 126, p. 203-218, 2013.

WALKLEY, A.; BLACK, I. A. An examination of the degtyareff method for determining soil organic matter and proposed modification of the cromic titration method. Soil Science, v. 37, p. 29-38, 1934. 